\title{
Eesti sõnamuutmise uurimise lühiülevaade
}

\author{
Annika Viht \\ Tallinna Ülikooli humanitaarteaduste instituudi eesti keele lektor \\ annika.viht@tlu.ee
}

\begin{abstract}
Teesid: 17.-18. sajandil kirjeldati eesti sõnamuutmist Euroopa traditsioonis tavalise ladina keeleõpetuse malli järgi, alternatiive otsiti aktiivselt 19. sajandi esimesel poolel. 19. sajandi teisel poolel ilmus põhjalik kirjeldav grammatika ja esimesed eestikeelsed keelekirjeldused. Eesti keeleteaduse esimesed uurimisdistsipliinid keeleajalugu ja murdeuurimine kujunesid välja 1920.-30. aastail, hiljem on lisandunud kirjakeele ajalugu, esimese keele omandamine, argikeele uurimine, arvutilingvistika ja teise keele omandamine. Sõnamuutmisteoreetiliste küsimustega tegeldi iseäranis intensiivselt 1960.-90. aastail, mh töötasid oma morfoloogiamudelid välja Ülle Viks, Toomas Help, Henn Saari ja Martin Ehala, 2000. aastate olulisimate käsitluste sekka kuuluvad James Blevinsi ülevaated eesti sõnavormistikust. Vormimoodustusest enam on viimastel kümnenditel jälgitud vormikasutust.
\end{abstract}

Märksõnad: grammatika, keeleteaduse ajalugu, keeleteooria, sõnamuutmine, uurimissuunad

\section{Eesti sõnamuutmise uurimise lühiülevaade}

Sõnamuutmine ehk muutemorfoloogia on grammatilise info edastamine sõnavormidega. Eesti keele uurijad on pühendanud sellele valdkonnale palju tähelepanu, kuna käänd- ja pöördsõnadel on kümneid vorme ning vormide moodustus varieerub sõnuti ulatuslikult. Sõnamuutmise uurimise pikast ajaloost on koostatud hulk ülevaateid (Mihkla 1927-28; Ehala \& Kaalep et al. 2003; Kasik 2011 jt), millest värskeim ilmub lühemal kujul siin ja pikemana monograafias "Eesti keele sõnamuutmine" (Habicht \& Viht ilmumas). 


\section{7.-18. sajand. Kontrastiivsed ladina raamistikus grammatikad}

Esimesed ülevaated eesti sõnamuutmissüsteemist ilmusid muulastele mõeldud eesti keele grammatikates, mille autoreiks olid kirikuõpetajad Heinrich Stahl (1637), Johannes Gutslaff (1648), Heinrich Göseken (1660), Johann Hornung (1693), Johann Christoph Clare (1720. aastad), Anton Thor Helle (1730) ja August Wilhelm Hupel (1780, 2. tr 1818). Eesti noomeni- ja verbivormistikku kirjeldati ladina keele kategooriate vahendusel, nagu oli Euroopa grammatikatraditsioonis juba sajandeid tavaks olnud.

Eesti noomeniparadigma esitas enamik grammatikuid kuuekäändelisena, paigutades sinna ladina käändetähendustele vastavad vormid. Nominatiiv ja vokatiiv vastasid tänapäeva nimetavale, akusatiiv alates Hornungi grammatikast osastavale ja genitiiv omastavale. Daativ hõlmas alale- ja alalütlevat (Gutslaffil ainult alaleütlevat), ablatiiv seest- ja alaltütlevat (Hornungil lisaks sisse- ja seesütlevat). Asjaolule, et osa käändsõnavorme jäi siiski kirjeldamata, juhtis tähelepanu juba esimese lõunaeesti grammatika autor Johannes Gutslaff, kelle sõnutsi oleks võimalik eesti käändesüsteemi käsitleda koosnevana algvormist (nimetavast) ja kõiki ülejäänud käändeid produtseerivast vormist (omastavast). Järgmiste grammatikate autorid jätsid siiski alles kõik ladina käänded ning tutvustasid neid eesti käändsõnavorme, mis ladina raamistikku ei mahtunud, käändsõna ja enkliitiku või käändsõna ja kaassõna ühendina. Näiteks tutvustas Hornung morfeeme ta, ga ja ni kui kaassõnu, mis kinnituvad sõna külge. Alates tema grammatikast kirjeldati paradigmaatiliste käänetena või mujal kõiki tänapäevaseid eesti käändevorme peale essiivi.

Verbivormistiku kirjeldus varieerus autoriti rohkem. Esimeses kolmes grammatikas sisaldas see saksa keelega sarnast futuurumit ja isikulist passiivi, edaspidistes põhjaeesti grammatikates enam mitte (lõunaeesti keele kirjeldustesse jäi futuurum alles). Kõneviisikategooria liikmetest hõlmas indikatiiv tänapäevast kindlat kõneviisi, imperatiiv käskivat kõneviisi, infinitiiv käändelisi, optatiiv enamjaolt tingivat kõneviisi ja konjunktiiv mitmesuguseid kaudsust väljendavaid vorme.

Muuttüübid puudusid täiesti üksnes esimeses grammatikas, edaspidi juhtisid kõik tähelepanu sellele, et kõik sõnad ei käändu-pöördu ühtviisi. Esimesena tõi hulga käändtüüpe välja Hornung. Samuti ei maininud Stahl oma grammatikas veel tüvevaheldusi, järgmise kahe grammatika autorid Göseken ja Gutslaff juhtisid tähelepanu laadivahelduslikele sõnadele ning nende järel kirjeldas Hornung tüvemuutuste esinemistingimusi lähemalt. Johann Hornung kirjeldas seega oma grammatikas eesti sõnamuutmist eelkäijatest süsteemsemalt ning kõneldava keelega paremas kooskõlas. (Kilgi 2007) 


\section{9. sajandi I pool. Uudsed soome-eeskujulised käsitlused}

19. sajandi algul hakati kritiseerima senist keelekirjeldust ning pakkuma uusi käsitlusvõimalusi. Arutelud näikse olevat vallandanud 1816. aastal Beiträge’s ilmunud artikkel, milles publitseeriti trükiootel soome grammatika noomenipeatükk 15 käändega (Strahlmann \& Rosenplänter 1816). Ehkki ajakirja väljaandja Rosenplänter soovitas oma kommentaaris jääda traditsioonilise käändekäsitluse juurde, ei olnud kõik kaastöölised temaga nõus.

Märganuna, et eesti keeleski on samalaadsed käänded, avaldas Arnold Friedrich Johann Knüpffer (1817) 13-käändelise loendi ja hiljem (1821) lisas ka neljateistkümnenda, na-lõpulise käände.

Grammatilisi käändeid käsitles põhjalikult Johann Friedrich Heller (1822; $1823 ;$ 1847). Heller rõhutas, et nominatiivi, genitiivi ja akusatiivi on ekslik nimetada eesti keele kääneteks, sest igale neist tähendustest vastab eesti keeles rohkem kui üks vorm, ning soovitas tänapäevase nimetava, omastava ja osastava nimetada ümber definitiiviks, relatiiviks ja indefinitiiviks. Läbinägelik oli ka tema tähelepanek (1822: 23; 1847), et eesti keele umbisikulise tegumoe vormid pole tegelikult passiiv nagu senistes käsitlustes, vaid impersonaalne aktiiv.

Friedrich Robert Faehlmann avaldas esimese süstemaatilise ülevaate astmevaheldusest (1843), eesti senise käändsõnakäsitluse kriitilise ülevaate (1846) ning jagas esmakordselt eesti sõnad muutkondadesse ühtselt aluselt (tüve lõpphääliku järgi) $(1842 ; 1844)$.

Kõige elavamalt arutlesid tollased keeleuurijad käänete üle ning arusaamad käände olemusest ja käändeparadigma koosseisust varieerusid palju. Lisaks varem mainituile kirjutasid käänetest veel näiteks Kristjan Jaak Peterson, kes juhtis (1818) tähelepanu sellele, et eesti kohakäänded moodustavad kaks kolmeliikmelist sarja, ja Wilhelm Friedrich Steingrüber, kes kritiseeris (1825) Knüpfferi käändekäsitlust.

Esimese tervikliku uutest arusaamadest lähtuva grammatika (1843; II, parandatud ja täiendatud trükk 1853) koostas Eduard Ahrens, kusjuures kõige põhjalikumalt töötas ta läbi sõnamuutmise käsitluse, mis kehtib üldjoontes samasugusena tänapäevani (Ross 2003: 10). 


\section{5. aasta. Wiedemanni deskriptiivne grammatika}

Ehkki Ferdinand Johann Wiedemann tegutses võrdlev-ajaloolise keeleteaduse hiilgeajal, koostas ta hoopis oma kaasaegset keelt kirjeldava grammatika, mida oli tema hinnangul kõigepealt tarvis (Wiedemann 1875: I). Tema rohkesti keelenäiteid sisaldav deskriptiivne grammatika (1875) ületas nii ulatuselt kui ka analüüsi põhjalikkuselt kõiki seniseid eesti keele käsitlusi. Erinevalt eelmistest ja järgmistest grammatikatest, mis olid normatiivsed, kirjeldas ta kõike kirjakeeles ja murdeis märgatut. (Alvre 1975: 723, 726)

\section{9. sajandi teine pool ja 20. sajandi algus. Esimesed eestikeelsed uurimused}

19. sajandi viimasel veerandil ilmusid esimesed eestikeelsed eesti grammatika tutvustused. Esimene eestikeelne keeleteaduslik raamat, Mihkel Veske "Eesti keele healte õpetus ja kirjutuse viis" (1879) kirjeldas ka sõnade vormistikku, kuid keskendus foneetikale. Esimese täieliku eestikeelse grammatika (1884) avaldas Karl August Hermann, kelle loodud grammatikaterminoloogiast on suur osa tänapäevani kasutusel. Autorid olid kaitsnud ka esimesed eesti keele teemalised doktoritööd (kolmanda kaitses Jakob Hurt). Sestsaadik hakkas ilmuma ridamisi eesti keele õpperaamatuid.

\section{Aastad 1918-1944. Traditsiooniliste uurimissuundade väljakujunemine}

Enne Eesti Vabariigi sündi tegeldi keeleuurimisega peamiselt asjaarmastajana (väheste eranditega, nt ülikooli eesti keele lektorid Faehlmann, Hermann ja Veske ning eelkõige akadeemik Wiedemann). Lingvistika arengule mõjus vabariigi sünd viljastavalt: eestikeelseks muudetud ülikoolis loodi rahvusteaduste uurimiseks ja õpetamiseks professuurid, ülikooli juures hakkasid tegutsema Akadeemiline Emakeele Selts ja taaselustatud Õpetatud Eesti Selts. (Mägiste 1937: 359-360, 479)

Väljakujuneva eesti keeleteaduse keskmes oli keeleajaloo ja murrete uurimine. Sel teemal avaldasid artikleid ja kaitsesid doktoritöö Andrus [Albert] Saareste (1924), Julius Mark (1923, ilmunud 1925), Julius Mägiste (1928), Mihkel Toomse (1941) ning Alo Raun (1941). Ilmus ka kirjakeele ajaloo põhjalikumaid käsitlusi allikatutvustustena (Saareste 1923; 1930; 1938; 1940; 
Mägiste 1930) ning Mägistelt ja Saarestelt esimesed tervikülevaated (kirja) keele pikemate perioodide kohta (Mägiste 1936; Saareste 1937; 1939; 1940).

Kaasaegset keelt uuriti see-eest vähe ning eelkõige keelehooldelisest vaatenurgast (Kasik 2011: 18). Normikeelt tähtsustavail 1930. aastail ilmus ülevaateid tekstidest leitud eksimustest kirjakeele normingute vastu, enamjaolt analüüsiti õpilaste eksamitöid (nt Aavik 1935; 1936b; Meos 1936; Nurm 1939). Kõige ulatuslikuma ülevaate kirjakeele reeglitest ja eksimustest nende vastu andis Johannes Aavik (1936a).

Enamjaolt avaldati aga uurimusliku osata keelekorralduslikke kirjutisi. Kirjakeele korraldamise üle arutleti Eesti Vabariigi esimesel iseseisvusajal intensiivselt. Keelemeeste vaated erinesid seejuures tugevalt ning tollases keelehooldes võib täheldada nelja põhisuunda: keeleuuenduslikku (Johannes Aavik, Villem Grünthal-Ridala, Oskar Loorits jt), reeglipärasust taotlevat (Johannes Voldemar Veski, Elmar Muuk), keele loomulikku arengut pooldavat (Jaan Jõgever, Kaarel Leetberg) ja demokraatlikku (Andrus Saareste) (vt Raag 2008: 181-186). Seejuures kestis keeleuuendusliku suuna kõrgaeg kuni Veski "Eesti õigekeelsuse-sõnaraamatu" I köite (1925) ja Elmar Muugi grammatika "Eesti keeleõpetus I. Hääliku- ja vormi õpetus" (1927) ilmumiseni. Nende ja järgmiste kirjakeele norminguid fikseerivate teoste toel hakkas valitsema reeglipärasuse suund, ülejäänud suunad seevastu olid keele range normimise vastu (Raag 2008: 192, 207).

\section{Aastad 1945-1960. Traditsiooniliste suundade kinnistumine}

1944. aastal lahkusid Eestist kõik doktorikraadiga keeleteadlased peale Paul Ariste ning kümmekond sõjajärgset aastat polnud siinses keeleuurimises kuigi viljakad (Kasik 2011: 18). Rootsi põgenenud keeleuurijad jätkasid oma tööd seal, Eestisse jäänud hakkasid siin taas eesti keele õpetamist ja uurimist üles ehitama.

Olulisim kodumaistest sõnamuutmisega tegelejatest oli kirjakeele ajaloo ja murrete uurija Arnold Kask, kes kaitses 1955. aastal doktoriväitekirja ja sai Tartu ülikooli eesti keele professoriks. Tema eestvõttel kujunes kirjakeele ajalugu omaette uurimisdistsipliiniks. Tema juhitud eesti keele kateedris kaitsti sõnamuutmisest hulk diplomitöid ning kaks kandidaadiväitekirja, milles Juhan Peegel (1954) kirjeldas vanema rahvalaulu vormimoodustust ja Aino Valmet (1956) mitmuse osastavat vanas kirjakeeles.

Tüüpjuhul jälgiti uurimistöödes sama keelenähtust keeleajaloos, murretes, vanemas ja kaasaegses kirjakeeles. Selline käsitlusviis oli saanud tavaks Eesti 
Vabariigi aegsetes Saareste, Mägiste, Toomse jt uurimustes. Sõnamuutmise uurimisel jätkatigi eelmistel kümnenditel kujunenud uurimissuundade ja -meetoditega, kirjeldades põhjalikult paljude üksikvormide ajalugu ning jõudes ka kaalukate üldkäsitlusteni eesti keele muutumisest pikemal perioodil (nt Saareste 1952, Kask 1949, 1952). Koostati ka põhjalikke murdeülevaateid, mis ilmusid täiendatuna-toimetatuna aastakümneid hiljem (Must \& Univere 2002; Tanning 2004).

\section{0.-1990. aastad. Uurimise muutumine teooriakesksemaks}

1960.-1990. aastad olid eesti sõnamuutmise uurimises väga produktiivsed, ilmus rohkesti niihästi teoreetilisi alusuuringuid kui ka palju konkreetse keeleainese analüüse, jõudsalt edenesid traditsioonilised uurimissuunad ja nende kõrval said alguse uued.

Esimesed morfoloogiateoreetilised artiklid ilmusid 1960. aastatel, kui Henno Rajandi (1963) ja Valmen Hallap (1964a; 1964b) tutvustasid strukturalistlikku IA-mudelit, mis jagab millise tahes teksti morfeemijadaks. 1970. aastate algul demonstreeris Mati Hint (1972), et eesti flektiivseid vorme kirjeldab märksa otstarbekamalt IP-mudel, mis annab üldistavad reeglid lähtevormist ülejäänud vormide moodustamiseks. 1977. a ilmus Ülle Viksilt ülevaade olulisematest morfoloogiamudelitest, ühtlasi tutvustas ta enda välja töötatud klassifikatoorse morfoloogia mudelit, mida ta edaspidi täiendas ja optimeeris ning tegi sellega seoses laialdasi empiirilisi uuringuid (Viks 1978; 1980; 1982a; 1982b; 1992 jt). Veel töötas Toomas Help välja WA-mudeli (1985b; 1985c; 1995; 2004), Henn Saari GSS-morfoloogia (1997; 1998; 1999) ja Martin Ehala AB-grammatika (1997).

Arutleti ka morfoloogiliste kategooriate olemuse üle. Senisele kõneviisi määratlusele pakkus alternatiivi Huno Rätsep (1971), öeldes, et kui kasutada kõneviisiülest teatelaadikategooriat (tänapäevase terminiga evidentsiaalsust), on eesti keeles kolm kõneviisi, kusjuures kindlal ja käskival kõneviisil on kaks varianti: otsese ja vahendava teatamislaadiga. Tiit-Rein Viitso tegi ettepaneku hakata vahendava teatamislaadiga käsuvorme tõlgendama omaette kõneviisina (1976) ning mõne aja pärast ilmunud kirjeldavas grammatikas (EKG I 1995) nii tehtigi. Käändekategooriale heitis värske pilgu Toomas Help (1985a; 1998). Ta käsitles eesti käändevorme kombinatsioonidena, mille võisid moodustada primaarkääne (kas nominatiiv või obliikva), sekundaarkääne (partitiiv, illatiiv, inessiiv, elatiiv, allatiiv, adessiiv, ablatiiv, translatiiv) ja kliitik ( $n i, n a, t a$, ga). Rajava, oleva, ilma- ja kaasaütleva tunnuseid kirjeldas mitmes tollases 
artiklis kliitikutena ka Joel Nevis (1986; 1988). Käändekirjeldus jäi erinevalt kõneviisikategooria koosseisust EKGs siiski traditsiooniliseks.

1970. aastate lõpus hakati keelenähtusi vaatlema tsentri ja perifeeria põhimõttel, eristades sõnaliigi (Erelt 1977), käändekategooria (Kross 1988, valminud 1978) ja muuttüübistiku (Kross 1984; Help 1985b; 1985c) tüüpilisi ja ebatüüpilisi esindajaid. Sellega haakuvalt hakati teadlikult rõhutama vormimoodustusnähtuste produktiivsust: ilmus Kristiina Rossi noomenitüüpide produktiivsuse analüüs (Kross 1984) ning Toomas Help rõhutas vajadust eristada mälus tervikuna säilitatavaid vorme ehk passiivset morfoloogiat sellistest vormidest, mida moodustatakse reeglitega, mis järelduvad sõna häälikkuju põhjal automaatselt ehk aktiivset morfoloogiat (Help 1985b; 1985c jj).

Paljud osutasid ebakohtadele sõnamuutmise teaduslikus käsitluses, õpetamises ja normimises ning pakkusid ideid, kuidas seda võiks paremini korraldada. Mati Hint, Jaak Peebo jt tegid ulatuslikke argikeele uuringuid (Hint 1979; 1980a; 1980b; 1980c; Peebo 1982; 1999; Kaljumägi 1999; Keevallik 1994 jt), millest osa sai normingumuudatuste aluseks.

Jõudsalt liikusid edasi ka traditsioonilised uurimissuunad. Kitsamate teemade põhjalike käsitluste kõrval valmisid üldistavad ülevaated noomenimorfoloogia ajaloost (Rätsep 1979; 1982), kirjakeele arengust ja selle murdetaustast (Kask 1962; 1984), Aaviku morfoloogiaettepanekute käekäigust (Raag 1998) ning tänapäeva eesti keele vormimoodustusest sõnatüübiti (Peebo 1997), samuti ühe murde morfoloogia koondkäsitlused (Tanning 1961; Must 1965; Keem 1970; Must 1987; Must 1995; Univere 1996). Hakati rakendama uudseid meetodeid, nt hakkasid Mati Hint (1978), Kristiina Ross (Kross 1984) jt lähtuma loomuliku morfoloogia teooriast ning Karl Pajusalu (1995) ja Leelo Keevallik (1994) tõid morfoloogia variatiivsuse uurimisse kvantitatiivse sotsiolingvistika.

Uue uurimissuunana hakati 1970. aastail (kodu-Eestis 1990. aastail) jälgima laste vormimoodustuse omandamist. Hoogsalt edenes arvutilingvistika. 1970.-1980. aastail koostati formaliseeritud ja kvantitatiivseid keelekirjeldusi ning tehti keele automaattöötluseks vajalikke eeltöid. 1990. aastail asuti koostama ja morfoloogiliselt märgendama elektroonilisi tekstikorpusi, töötati välja morfoloogiaanalüsaatorid ja -ühestajad ning kirjeldati asjakohast problemaatikat artiklites, ühes doktori- (Kaalep 1999) ja kahes magistritöös (Puolakainen 1996; Uibo 1999).

Põhjaliku deskriptiivse grammatika koostamise plaani hakati pidama juba 1950. aastatel, kuid töö jäi pooleli ning ilmusid vaid grammatika üksikud osad, sh puudutati sõnamuutmist üksnes arv- ja asesõna käsitlevas vihikus (Kask \& Palmeos 1965). Alles aastakümneid hiljem ilmus kirjeldav grammatika EKG, mille Kristiina Rossi koostatud morfoloogiaosa (1995) oli varasema traditsiooniga võrreldes täiesti uudne, tuginedes Ülle Viksi ja Toomas Helbi 
morfoloogiamudelitele. Ühemehetööna koostas Valter Tauli eksiilis esimese puhtsünkroonilise sünteesigrammatika, mille uudse lähenemisega morfoloogiaosa (eesti keeles 1972 ja inglise keeles 1973) vaatles esmakordselt põhjalikult vormide üksteisest tuletatavust ning käsitles astmevaheldust (Uibo \& Erelt 1982: 215-217).

\section{0.-2010. aastad. Morfosüntaksi ja rakenduslingvistika osakaalu suurenemine}

Uue aastatuhande kahe esimese kümnendi olulisimaid sõnamuutmisteoreetilisi käsitlusi on James Blevinsi artiklid (2005; 2007; 2008), kus ta kirjeldab eesti sõnade vormimoodustust sõnapõhise WP-morfoloogiamudeli abil ning põhjendab selle eeliseid morfeemipõhiste mudelite ees. Samuti on süüvitud käänete olemusse: Katrin Hiietam (2003) soovitas käsitleda akusatiivi taas käändekategooria liikmena, Merilin Miljan aga ei pidanud seda otstarbekaks ning analüüsis põhjalikult (sh doktoriväitekirjas 2008) ka ülejäänud grammatiliste käänete kasutust. Reeli Torn-Leesiku doktoritöö (2016) andis süsteemse ülevaate impersonaali- ja passiivikonstruktsioonide erinevusest.

Ulatuslikult on uuritud argikeelt. Tiit-Rein Viitso (2005), Virve Vihman (2002; 2007) ja Mati Erelt (2013) jälgisid kõnekeelseid kahekordse impersonaalimarkeeringuga vorme, Mati Erelt ja Helle Metslang (2004) mitmesuguseid uudseid käsu- ja keeluvorme. Heiki-Jaan Kaalep (2015) esitas korpusuuringute põhjal verbi lihtvormide paradigma täpsustatud kujul, eemaldades sealt korpuses puudunud vormid ning lisades uusi. Kaalep on oma põhjalike korpusuuringute põhjal soovitanud täpsustada ka käändsõnakäsitlust (2009; 2010; 2012). On kaitstud mitukümmend üliõpilastööd vormikasutuse varieerumisest (nt Kio 2006; Pedaja 2006; Järvik 2011; Metslang 2012; Pedaja-Ansen 2015). Ann Siiman on uurinud, millised morfofonoloogilised, morfosüntaktilised ja semantilised tegurid mõjutavad rööpvormide kasutamist (Metslang 2015a; 2015b; Siiman 2016).

Palju on tegeldud rakenduslingvistiliste teemadega, eriti sõnamuutmise omandamisega. Uute ja viljakate uurimissuundadena on välja kujunenud eesti keele kui teise keele omandamise ning alakõnega lapse keeleomandamise uurimine, märgatavalt on hoogustunud ka eesti keele kui esimese keele omandamise uurimine. Viimasest on doktoriväitekirja kaitsnud Sirje Hassinen (2002), Kaja Kohler (2003) ja Reili Argus (2008). Arvutuslingvistid on peamiselt täiustanud eelmisel sajandil välja töötatud morfoloogiaprogramme ja -kirjeldusi.

Traditsioonilistest uurimissuundadest on väga heal järjel murdemorfoloogia uurimine, ilmunud on mitme murde tervikülevaated (Juhkam \& Sepp 2000; 
Lonn \& Niit 2002; Keem \& Käsi 2002; Mets \& Haak et al. 2014) ning koostatud (peamiselt lõunaeesti murde kohta) hulk sõnamuutmisuurimusi, sh on võru kirja- ja kõnekeelest doktoritöö kaitsnud Sulev Iva (2007) ja Mari Mets (2010). Samuti on paljudes uurimustes jälgitud kirjakeelsete tekstide vormikasutust, vana kirjakeele verbimorfoloogiast on kaitsnud doktoritööd Katja Ziegelmann (2011) ja Annika Viht (Kilgi 2012). Võrreldes varasemaga on vähem uuritud vormide ajalugu, sellega on viimastel kümnenditel tegelnud peaaegu ainult Ago Künnap (2013 jt) ja Tiit-Rein Viitso (2003 jt).

Vormimoodustusest märksa enam on viimastel kümnenditel aga jälgitud vormide kasutust lauses, eriti argikeele, teise keele omandamise ja kirjakeele ajaloo uurimisel. Muu hulgas on analüüsitud sihitise vormivalikut (nt Pool 2007; Eslon \& Õim 2010) ja infiniitvorme vana kirjakeele verbikonstruktsioonides (nt Penjam 2008; Ross 2009). Paljud morfosüntaktilised uurimused lähtuvad tähendusest, kirjeldades sama ülesande täitmiseks kasutatavaid erisuguseid (nii grammatilisi kui ka leksikaalseid) keelevahendeid. Iseäranis palju on uuritud evidentsiaalsuse (nt Kehayov 2008) ja modaalsuse (nt Metslang 2006) väljendusvahendeid. On lähenetud ka teistpidi, kirjeldades sama vormi kasutust erisugustes funktsioonides, nt tingiva kõneviisi (Pajusalu \& Pajusalu 2004) ja kaasaütleva käändega (Metslang \& Habicht et al. 2017) väljendatavaid tähendusi. Samuti on põhjalikult analüüsitud mitmesuguseid tuumverbidega moodustatavaid konstruktsioone, nt saama-verbi tarindeid (Tragel \& Habicht 2017).

\section{Kirjandus}

Aavik, Johannes 1935. Gümnaasiumi lõpuklassi õpilaste võistluskirjandid. Eesti Kool 7, lk 269-282; 8, lk 356-366.

Aavik, Johannes 1936a. Eesti õigekeelsuse õpik ja grammatika. Tartu: Noor-Eesti.

Aavik, Johannes 1936b. Keel ja stiil gümnaasiumiõpilaste võistluskirjandeis. Eesti Kool 4, lk 165-176.

Ahrens, Eduard 1843. Grammatik der Ehstnischen Sprache Revalschen Dialektes. Erster Theil: Formenlehre. Reval: Heinrich Laakmann.

Alvre, Paul 1975. Sada aastat Wiedemanni eesti keele grammatikat. Keel ja Kirjandus 12 , lk 715-726.

Argus, Reili 2008. Eesti keele muutemorfoloogia omandamine. Tallinna Ülikooli humanitaarteaduste dissertatsioonid 19. Tallinn: Tallinna Ülikooli Kirjastus (http:// www.etera.ee/zoom/2183 - 6. oktoober 2017).

Blevins, James 2005. Word-based declensions in Estonian. Yearbook of Morphology 2005, lk 1-25 (doi: 10.1007/1-4020-4066-0_1). 
Blevins, James 2007. Conjugation classes in Estonian. Linguistica Uralica 43 (4), lk 250-267.

Blevins, James 2008. Declension classes in Estonian. Linguistica Uralica 44 (4), lk 241267 (doi: 10.3176/lu.2008.4.01).

Clare, Johann Christoph 1730. Kurtzer Entwurfeiner Gramatik. Käsikiri Eesti Kirjandusmuusemis.

Ehala, Martin \& Kaalep, Heiki-Jaan \& Kilgi, Annika \& Viks, Ülle 2003. Tänapäeva eesti kirjakeele uurimine: morfoloogia. Erelt, Mati (toim). Eesti keele uurimise analüüs. Emakeele Seltsi aastaraamat 48 (2002). Tallinn: Eesti Teaduste Akadeemia, lk 36-48.

Ehala, Martin 1997. Eesti morfoloogia olemus. Keel ja Kirjandus 6, lk 370-383.

EKG I 1995 = Erelt, Mati \& Kasik, Reet \& Metslang, Helle \& Rajandi, Henno \& Ross, Kristiina \& Saari, Henn \& Tael, Kaja \& Vare, Silvi. Erelt, Mati \& Erelt, Tiiu \& Saari, Henn \& Viks, Ülle (toim). Eesti keele grammatika I. Morfoloogia. Sõnamoodustus. Tallinn: Eesti Keele Instituut.

Erelt, Mati \& Metslang, Helle 2004. Grammar and Pragmatics: Changes in the Paradigm of the Estonian Imperative. Linguistica Uralica 40 (3), lk 161-178.

Erelt, Mati 1977. Ebamäärasusest sõnade liigitamisel. Keel ja Kirjandus 9, lk 525-528.

Erelt, Mati 2013. Keeldkõne vormidest. Emakeele Seltsi aastaraamat 58 (2012), lk 30-38 (http://kirj.ee/public/ESA/2012/esa_58-2012-30-38.indd.pdf - 6. oktoober 2017).

Eslon, Pille \& Õim, Katre 2010. Objektikäänete kasutamisest sageduse ja markeerituse seisukohalt. Eesti ja Soome-ugri Keeleteaduse Ajakiri 1-2, lk $69-89$ (http://jeful.ut.ee/ public/files/eslon-oim-esuka2.pdf - 6. oktoober 2017).

Faehlmann, Friedrich Robert 1842. Versuch die estnischen Verba in Conjugationen zu ordnen. Dorpat: Heinrich Laakmann.

Faehlmann, Friedrich Robert 1843. Ueber die Flexion des Wortstammes in der estnischen Sprache. Verhandlungen der gelehrten Estnischen Gesellschaft zu Dorpat 1: 2, lk 15-26.

Faehlmann, Friedrich Robert 1844. Ueber die Declination der estnischen Nomina. Verhandlungen der gelehrten Estnischen Gesellschaft zu Dorpat 1 (3), lk 17-61.

Faehlmann, Friedrich Robert 1846. Nachtrag zur Declinationslehre. Verhandlungen der gelehrten Estnischen Gesellschaft zu Dorpat 1 (4), lk 19-33.

Gutslaff 1648 = Lepajõe, Marju \& Peebo, Jaak (toim). Gutslaff, Johannes 1998. Observationes Grammaticae circa linguam Esthonicam. Grammatilisi vaatlusi eesti keelest. Tartu Ülikooli eesti keele õppetooli toimetised 10. Tartu: Tartu Ülikooli Kirjastus. Göseken, Heinrich 1660. Manuductio ad Linguam Oesthonicam. Reval: Adolph Simon. Habicht, Külli \& Viht, Annika ilmumas. Eesti keele sõnamuutmine. Eesti keele varamu 4. Tartu: Tartu ülikooli kirjastus.

Hallap, Valmen 1964a. Morfeemilise positsiooni mõiste. Keel ja Kirjandus 5, lk 283-289.

Hallap, Valmen 1964b. Morfemaatika küsimusi. Emakeele Seltsi aastaraamat 10 (1964), lk 3-22. 
Hassinen, Sirje 2002. Simultaaninen kaksikielisyys. Läheiset sukukielet viro ja suomi rinnakkain. Acta Universitatis Ouluensis, Humaniora, B 43. Oulu: Oulu University Press (http://herkules.oulu.fi/isbn951426648X/isbn951426648X.pdf - 18. september 2017).

Helle, Anton Thor 1732. Kurtzgefaßte Anweisung Zur Ehstnischen Sprache. Halle: Stephan Orban.

Heller, Johann Friedrich 1822. Versuch über das Wesen und Gebrauch der ehstn. Casen, besonders des sogenannten Nominativs, Genitivs und Accusativs. Beiträge 15, lk 1-42.

Heller, Johann Friedrich 1823. Nachtrag zu dem Versuche über das Wesen und den Gebrauch der ehstn. Casen, im 15ten Hft. dieser Beiträge. Beiträge 16, lk 1-27.

Heller, Johann Friedrich 1847. Vertheidigung meiner Ansicht von dem Verbum Passivum und von den Hauptcasen in der estnischen Grammatik. Veranlasst durch Dr Fählmann's "Nachtrag zur Declinationslehre" in Bd. 1, Heft 4 dieser "Verhandlungen", und vorgetragen in der gel. Estn. Gesellschaft am 16. Januar 1847. Verhandlungen der gelehrten Ehstnischen Gesellschaft zu Dorpat 2 (1), lk 23-45.

Help, Toomas 1985a. Eesti obliikva. Noored filoloogias 1985: Noorteadlaste XII konverents 22. mail. Teesid. Tallinn, lk 3-10.

Help, Toomas 1985b. Linguistic competence and morphology. Preprint KKI-38. Tallinn: Eesti NSV Teaduste Akadeemia.

Help, Toomas 1985c. Üks võimalus eesti verbimorfoloogia käsitlemiseks. Keel ja Kirjandus 4, lk 212-226.

Help, Toomas 1995. Regulaarsed ja irregulaarsed verbid eesti keeles. Keel ja Kirjandus 3 , lk 162-169; 4, lk 234-238; 5, lk 320-327.

Help, Toomas 1998. Eelistame enda oma ("Muutuv keel”). Keel ja Kirjandus 12, lk 812 815.

Help, Toomas 2004. Sõnakeskene keelemudel: eesti regulaarne ja irregulaarne verb. Dissertationes philologiae estonicae Universitatis Tartuensis 13. Tartu: Tartu Ülikooli Kirjastus. (http://dspace.ut.ee/handle/10062/575?locale-attribute=en - 19. september 2017).

Hermann, Karl August 1884. Eesti keele Grammatik. Koolide ja iseõppimise tarvis kõikidele, kes Eesti keelt õigesti ja puhtasti kõnelema ja kirjutama ning sügavamalt tundma ja uurima tahavad õppida. Tartu: Wilhelm Just.

Hiietam, Katrin 2003. Definiteness and Grammatical Relations in Estonian. University of Manchester. Department of Linguistics. Doctoral dissertation.

Hint, Mati 1972. Eesti keele morfoloogia kirjeldamise metoodika probleeme. Keel ja Kirjandus 10, lk 603-615.

Hint, Mati 1978. Kas olevik vajab tunnust. Keel ja Kirjandus 8, lk 475-480.

Hint, Mati 1979. Minevikuline ja tulevikuline aines keelesüsteemis. Nõrgaastmeline $i$-mitmus. Keel ja Kirjandus 3, lk 142-149; 4, lk 200-208.

Hint, Mati 1980a. Astmevahelduslike ja astmevaheldusetute tüüpide piirist kooligrammatikas. Nõukogude Kool 5, lk 30-34; 6, lk 19-24. 
Hint, Mati 1980b. Minevikuline ja tulevikuline aines keelesüsteemis. Prosoodiasüsteemi nihked ja selle tagajärjed. Keel ja Kirjandus 4, lk 215-223; 5, lk 270-278; 6, lk 349-355.

Hint, Mati 1980c. Võrdlusastmete morfoloogia raskused. Nõukogude Kool 2, lk 29-36.

Hornung, Johann 1693. Grammatica Esthonica, brevi, Perspicua tamen methodo ad Dialectum Revaliensem. Riga: Literis Joh. Georg Wilck.

Hupel, August Wilhelm 1780. Ehstnische Sprachlehre für beide Hauptdialekte, den revalschen und doerptschen; nebst einem vollstaendigen Woerterbuch. Riga \& Leipzig: Hartknoch.

Iva, Sulev 2007. Võru kirjakeele sõnamuutmissüsteem. Dissertationes philologiae estonicae Universitatis Tartuensis 20. Tartu: Tartu Ülikooli Kirjastus (http://dspace. ut.ee/handle/10062/4860 - 6. oktoober 2017).

Juhkam, Evi \& Sepp, Aldi 2000. Läänemurde tekstid. Eesti murded VIII. Tallinn: Eesti Keele Instituut.

Järvik, Elise 2011. Laadivahelduse taandumine eesti kirjakeeles. Magistritöö. Käsikiri Tartu Ülikooli eesti ja üldkeeleteaduse instituudis (http://www.murre.ut.ee/arhiiv/ naita_pilt.php?materjal=kasikiri\&materjal_id=D1674\&sari=D - 19. september 2017).

Kaalep, Heiki-Jaan 1999. Eesti keele ressursside loomine ja kasutamine keeletehnoloogilises arendustöös. Dissertationes Philologiae Estonicae Universitatis Tartuensis 7. Tartu: Tartu Ülikooli Kirjastus.

Kaalep, Heiki-Jaan 2009. Kuidas kirjeldada lühikest sisseütlevat kasutusandmetega kooskõlas? Keel ja Kirjandus 6, lk 411-425 (http://keeljakirjandus.eki.ee/411-425.pdf 19. september 2017).

Kaalep, Heiki-Jaan 2010. Mitmuse osastav eesti keele käändesüsteemis. Keel ja Kirjandus 2, lk 94-111 (http://keeljakirjandus.eki.ee/Kaalep94-111.pdf-19. september 2017).

Kaalep, Heiki-Jaan 2012. Eesti käänamissüsteemi seaduspärasused. Keel ja Kirjandus 6, lk 418-449 (http://keeljakirjandus.ee/pdf/HJK.pdf - 19. september 2017).

Kaalep, Heiki-Jaan 2015. Eesti verbi vormistik. Keel ja Kirjandus 1, lk 1-15 (http:// keeljakirjandus.eki.ee/411-425.pdf - 19. september 2017).

Kaljumägi, Karin 1999. Ohtlik- ja kontsert-tü̈̈pi sõnade kriitiliste morfoloogiliste vormide kasutusest. Magistritöö. Käsikiri Tartu Ülikooli eesti ja üldkeeleteaduse instituudis.

Kasik, Reet 2011. Stahli mantlipärijad. Eesti keele uurimise lugu. Tartu: Tartu Ülikooli Kirjastus.

Kask, Arnold 1962. Eesti kirjakeele murdelise tausta kujunemisest. Tartu: Tartu Riiklik Ülikool.

Kask, Arnold 1984. Eesti murded ja kirjakeel. Emakeele Seltsi toimetised 16. Tallinn: Valgus.

Kask, Arnold \& Palmeos, Pauline 1965. Eesti keele grammatika. 2., Morfoloogia. Arv- ja asesõna. Tartu: Tartu Riiklik Ülikool.

Keem, Hella 1970. Tartu murde tekstid. Eesti murded III. Tallinn: Valgus. 
Keem, Hella \& Käsi, Inge 2002. Võru murde tekstid. Eesti murded VI. Tallinn: Eesti Keele Instituut.

Keevallik, Leelo 1994. <nud> varieerumine tänapäeva eesti kõnekeeles. Magistritöö. Tartu (https://www.liu.se/ikk/medarbetare/leelo-keevallik/dokument/1.413523/Magister. pdf - 19. september 2017).

Kehayov, Petar 2008. An Areal-Typological Perspective to Evidentiality: the Cases of the Balkan and Baltic Linguistic Areas. Dissertationes Linguisticae Universitatis Tartuensis 10. Tartu: Tartu Ülikooli Kirjastus (http://dspace.ut.ee/handle/10062/6524 19. september 2017).

Kilgi, Annika 2007. Eesti morfoloogilise mõtte areng Stahlist Ahrensini. Magistritöö. Käsikiri Tallinna Ülikooli humanitaarteaduste instituudis.

Kilgi, Annika 2012. Tõlkekeele dünaamika Piibli esmaeestinduse käigus: verbi morfosüntaksi areng ja lõplik toimetamisfaas. Tallinna Ülikooli humanitaarteaduste dissertatsioonid 27. Tallinn: Tallinna Ülikooli Kirjastus (http://www.etera.ee/zoom/1955/ - 6. oktoober 2017).

Kio, Kati 2006. Sisseütleva käände kasutus eesti kirjakeeles. Magistritöö. Käsikiri Tartu Ülikooli raamatukogus (http://hdl.handle.net/10062/865 - 19. september 2017).

Knüpffer, Arnold Friedrich Johann 1817. Bemerkungen über die Declinations- und Casusformen der Ehstnischen Sprache. Dem Herrn Doctor der Theologie, Probst und Consistorial-Assessor David Gottlieb Glanström, zur Jubelfeyer des fünfzigsten Jahresfestes seiner Predigeramts-Führung, an den Kirchen zu Weissenstein und St. Annen, den 13ten Juny 1817. Reval: gedruckt bey Johann Hermann Gressel.

Knüpffer, Arnold Friedrich Johann 1821. Ueber das Suffix oder die Casus-Endung: na. Beiträge 13, lk 122-127.

Kohler, Kaja 2003. Erwerb der frühen Verbmorphologie im Estnischen. Dissertation in der Humanwissenschaftlichen Fakultät der Universität Potsdam. Potsdam (https:// publishup.uni-potsdam.de/opus4-ubp/frontdoor/deliver/index/docId/128/file/kohler.pdf 19. september 2017).

Kross, Kristiina 1984. Eesti noomeni muutmistü̈̈pide produktiivsus. Preprint KKI-26. Tallinn: Eesti NSV Teaduste Akadeemia.

Kross, Kristiina 1988. Instruktiiv läänemeresoome keeltes. Tallinn: Valgus.

Künnap, Ago 2013. Eesti keele päritolu. Tartu: Eesti Keele Sihtasutus.

Lonn, Varje \& Niit, Ellen 2002. Saarte murde tekstid. Eesti murded VII. Tallinn: Eesti Keele Sihtasutus.

Mark, Julius 1925. Die Possessivsuffixe in den uralischen Sprachen. Suomalais-ugrilaisen seuran toimituksia, 1. Hälfte (54). Helsinki: Suomalais-ugrilainen seura.

Meos, Märt 1936. Eesti algkooli lõpetaja: algkooli lõpetaja oskused ja teadmised emakeele alal. Tallinn: Tallinna Eesti Kirjastus-Ühisus.

Mets, Mari 2010. Suhtlusvõrgustikud reaalajas: võru kõnekeele varieerumine kahes Võrumaa külas. Dissertationes philologiae estonicae Universitatis Tartuensis 25. Tartu: Tartu Ülikooli Kirjastus (http://hdl.handle.net/10062/14781 - 19. september 2017). 
Mets, Mari \& Haak, Anu \& Iva, Triin \& Juhkason, Grethe \& Kalmus, Mervi \& Norvik, Miina \& Pajusalu, Karl \& Teras, Pire \& Tuisk, Tuuli \& Vaba, Lembit 2014. Lõunaeesti keelesaarte tekstid. Eesti murded IX. Tallinn: Eesti Keele Instituut, Tartu: Tartu Ülikool.

Metslang, Ann 2012. Varieeruva vormistikuga muuttü̈̈pide osastava käände kasutus eesti kirjakeeles. Magistritöö. Käsikiri Tartu Ülikooli eesti ja üldkeeleteaduse instituudis http:// www.murre.ut.ee/arhiiv/naita_pilt.php?materjal=kasikiri\&materjal_id=D1726\&sari=D_ 19. september 2017).

Metslang, Ann 2015a. Ainsuse pika ja lühikese sisseütleva valiku olenemine morfofonoloogilistest tunnustest - korpusanalüüs. Emakeele Seltsi aastaraamat 60 (2014), lk 127-147 (http://kirj.ee/public/ESA/2015/esa_61_2015_207_232.pdf - 6. oktoober 2017).

Metslang, Ann 2015b. Mitmuse osastava sid- ja si-lõpu varieerumise kasutuspõhine analüüs. Keel ja Kirjandus 11, lk 792-803 (http://kjk.eki.ee/pdf/Ann_Metslang11-15. pdf - 19. september 2017).

Metslang, Helle 2006. Imperatiivist ja direktiivsusest ning nende dünaamikast eesti ja soome keeles. Metslang, Helle \& Soidro, Siiri (toim). Lähivertailuja 16. Soome-eesti kontrastiivseminar 8.-9.05.2004 Männikul. Tallinna Ülikooli eesti filoloogia osakonna toimetised 7. Tallinn: Tallinna Ülikooli Kirjastus, lk 111-134.

Metslang, Helle \& Habicht, Külli \& Hennoste, Tiit \& Jürine, Anni \& Laanesoo, Kirsi \& Ogren, David 2017. Artikkel õnnesoovidega. Komitatiivi funktsioonidest eri aegade ja registrite eesti kirjakeeles. Eesti ja Soome-ugri Keeleteaduse Ajakiri 1, lk 147-178 (http://jeful.ut.ee/index.php/JEFUL/article/view/jeful.2017.8.1.09 - 6. oktoober 2017).

Mihkla, Karl 1927. Eesti vormi- ja tuletusõpetuste ülevaade (1637-1927). Eesti Kirjandus 8, lk 446-464; 9, lk 495-502; 10, lk 536-543; 11, lk 613-618; 12, lk 641-649.

Mihkla, Karl 1928. Eesti vormi- ja tuletusõpetuste ülevaade (1637-1927) (järg). Eesti Kirjandus 3, lk 147-160; 5, lk 262-275; 7, lk 361-378; 12, lk 642-653.

Miljan, Merilin 2008. Grammatical case in Estonian. Käsikiri Edinburghi ülikoolis (https:// www.era.lib.ed.ac.uk/bitstream/handle/1842/4035/Miljan2009. pdf-20. september 2017).

Must, Mari 1965. Keskmurde tekstid. Eesti murded II. Tallinn: Eesti NSV Teaduste Akadeemia Keele ja Kirjanduse Instituut.

Must, Mari 1987. Kirderannikumurre: häälikuline ja grammatiline ülevaade. Tallinn: Valgus.

Must, Mari 1995. Kirderannikumurde tekstid. Eesti murded V. Tallinn: Eesti Teaduste Akadeemia Eesti Keele Instituut.

Must, Mari \& Univere, Aili 2002. Põhjaeesti keskmurre. Häälikulisi ja morfoloogilisi peajooni. Eesti Keele Instituudi toimetised 10. Tallinn: Eesti Keele Sihtasutus.

Mägiste, Julius 1928. oi-, ei-deminutiivid läänemeresoome keelis: läänemeresoome nominaaltuletus. Tartu: Postimees.

Mägiste, Julius 1930. Vanim eestikeelne trükkteos aastast 1535. Eesti Kirjandus 10, lk 484-490. 
Mägiste, Julius 1936. Vaimne kultuur: keel. Moora, Harri \& Laid, Eerik \& Mägiste, Julius \& Kruus, Hans (toim). Eesti ajalugu I. 2. trükk. Tartu, lk 120-121, lk 232-237.

Mägiste, Julius 1937. Rahvuslike teaduste edust Eestis. Looming 3, lk 358-361; 4, lk 470-486.

Nevis, Joel 1986. The comitative, terminative, abessive, and essive as clitics in Estonian. Ural-Altaische Jahrbücher 7, lk 79-98.

Nevis, Joel 1988. On the development of the clitic postposition category in Estonian. Finnisch-Ugrische Forschungen 48, lk 171-197.

Nurm, Ernst 1939. Ülevaade 1056 keskkoolilõpetaja õigekirja ning õigekeelsuse tasemest. Akadeemilise Emakeele Seltsi toimetised 40. Tartu: Akadeemiline Emakeele Selts.

Pajusalu, Karl 1995. Parree ja param. Kaksitavuisten A-vartaloiden komparatiivin kehityslinjoja suomessa ja virossa. Rintala, Päivi (peatoim). Kielen ja kulttuurin satakunta. Juhlakirja Aimo Hakasen 60-vuotispäiväksi 1. 11. 1995. Turun yliopiston suomalaisen ja yleisen kielitieteen laitoksen julkaisuja 51. Turku, lk 190-221.

Pajusalu, Renate \& Pajusalu, Karl 2004. The conditional in everyday Estonian: Its form and functions. Linguistica Uralica 40: 4, lk 257-269.

Pedaja, Kati 2006. Uute laensõnade kohanemine eesti keele morfoloogilise süsteemiga. Magistritöö. Käsikiri Tartu Ülikooli eesti ja üldkeeleteaduse instituudis (http://dspace. ut.ee/handle/10062/672 - 20. september 2017).

Pedaja-Ansen, Anu 2015. Võrdevormid tänapäeva eesti keeles. Magistritöö. Käsikiri Tallinna Ülikooli humanitaarteaduste instituudis (http://www.etera.ee/zoom/4314 20. september 2017).

Peebo, Jaak 1982. muuseum-tüüpi sõnade käänamisest. Keel ja Kirjandus 8, lk 431-435.

Peebo, Jaak 1997. Eesti keele muutkonnad. Tartu Ülikooli eesti keele õppetooli toimetised 5. Tartu: Tartu Ülikooli Kirjastus.

Peebo, Jaak 1999. Kahetüvelisuse taandumisest hammas- ja tütar-tüüpi sõnades. - Vaba, Lembit \& Hurtta, Heikki (toim). Lähivertailuja 10. Suomalais-virolainen kontrastiivinen seminaari Tampereella 14. toukokuuta 1998. Tampere: Tampereen yliopisto, lk 61-73.

Peegel, Juhan 1954. Eesti vanade rahvalaulude keele morfoloogia. Kandidaadiväitekiri. Käsikiri Tartu ülikooli raamatukogus.

Penjam, Pille 2008. Eesti kirjakeele $d a$ - ja $m a$-infinitiiviga konstruktsioonid. Dissertationes philologiae Estonicae Universitatis Tartuensis 23. Tartu: Tartu Ülikooli Kirjastus (http://dspace.ut.ee/handle/10062/7766 - 6. oktoober 2017).

Peterson, Kristjan Jaak 1818. Syntaktische Regeln. Ueber den Gebrauch des Nom. Gen. und Acc. bei einem Verb. Act. Ueber den Gebrauch der beiden Ablative im Ehstnischen. Beiträge 12, lk 145-149.

Pool, Raili 2007. Eesti keele teise keelena omandamise seaduspärasusi täis-ja osasihitise näitel. Dissertationes philologiae estonicae Universitatis Tartuensis 19. Tartu: Tartu Ülikooli Kirjastus (http://dspace.ut.ee/handle/10062/2237 - 20. september 2017). 
Puolakainen, Tiina 1996. Eesti keele morfoloogiline ühestamine kitsenduste grammatika abil. Magistritöö. Käsikiri Tartu Ülikooli raamatukogus.

Raag, Raimo 2008. Talurahva keelest riigikeeleks. Tartu: Atlex.

Raag, Virve 1998. The effects of planned change on Estonian morphology. Studia uralica upsaliensia 29. Uppsala: Universitet Uppsala.

Rajandi, Henno 1963. Morfeemide liigitus deskriptiivses lingvistikas. Keel ja Kirjandus 6, lk 357-361; 7, lk 409-414.

Raun, Alo 1941. Zur Komparation in den finnisch-ugrischen Sprachen: Dissertation. Tartu.

Ross, Kristiina 2003. Saateks. Ross, Kristiina (koost, toim). Uue ajastu misjonilingvist: Eduard Ahrens 200. Tallinn: Eesti Keele Sihtasutus, lk 7-23.

Ross, Kristiina 2009. Kirjaliku eesti lause poole: tähelepanekuid paari käändelise verbivormi ja neid sisaldavate tarindite kirjakeelde sugenemisest. Keel ja Kirjandus 12, lk 889-907 (http://keeljakirjandus.eki.ee/Ross889-907.pdf - 20. september 2017).

Rätsep, Huno 1971. Kas kaudne kõneviis on kõneviis? Keel ja struktuur 5. Tartu: Tartu Ülikooli Kirjastus, lk 45-69 (http://hunoratsep.ut.ee/wp-content/uploads/2012/11/kas_ kaudne_koneviis_on_koneviis.pdf - 20. september 2017).

Rätsep, Huno 1979. Eesti keele ajalooline morfoloogia II. Õpivahend eesti filoloogia osakonna üliõpilastele. Tartu: Tartu Riiklik Ülikool.

Rätsep, Huno 1982. Eesti keele ajalooline morfoloogia I. Õpivahend eesti filoloogia osakonna üliõpilastele. Teine, parandatud ja täiendatud trükk. Tartu: Tartu Riiklik Ülikool.

Saareste, Andrus 1923. 400-a. vanune keeleline leid Eestis. Eesti Keel 4, lk 97-104; 5-6, lk 136-149.

Saareste, Andrus [Albert] 1924. Leksikaalseist vahekordadest Eesti murretes. I. Analüüs. Acta et Commentationes Universitatis Dorpatensis B 6.1. Tartu: Tartu ülikool.

Saareste, Andrus [Albert] 1930. Esimese eestikeelse raamatu Wanradt-Kõlli katekismuse keelest. Eesti Keel 4-5, lk 73-96.

Saareste, Andrus 1937. Eesti keel XIII-XVI sajandil. Eesti Keele Arhiivi toimetised 11. Tartu: Eesti Keele Arhiiv.

Saareste, Andrus 1938. Agenda Parva (1622) keelest. Eesti Keel 7-8, lk 196-213.

Saareste, Andrus 1939. Piibli keel ja rahvakeel. Eesti Keel 7-8, lk 174-226.

Saareste, Andrus 1940. Eesti keel Rootsi-Poola ajal. Eesti Keele Arhiivi toimetised 18. Tartu: Eesti ja Sugukeelte Arhiiv.

Saareste, Andrus 1952. Kaunis emakeel I. Lund: Eesti Kirjanike Kooperatiiv.

Saari, Henn 1997. Ein Weg zur Wortgrammatik: Am Beispiel des Estnischen. Erster Teil. Doktoriväitekiri eesti keele alal. Eesti Keele Instituudi toimetised 1. Tallinn: Eesti Keele Instituut. 
Saari, Henn 1998. Üks vormiõpetus (I). Vaimumõõgad. Keel ja Kirjandus 9, lk 606-621. Saari, Henn 1999. Üks vormiõpetus (II). Taksonoomia. Keel ja Kirjandus 2, lk 80-87; 3, lk 166-175.

Siiman, Ann 2016. Ainsuse sisseütleva vormi valiku seos morfosüntaktiliste ja semantiliste tunnustega - materjali ning meetodi sobivus korpusanalüüsiks. Emakeele Seltsi aastaraamat 61 (2015), lk 207-232 (http://kirj.ee/public/ESA/2015/esa_61_2015_207_232. pdf - 21. september 2017, doi: 10.3176/esa61.10).

Stahl, Heinrich 1637. Anführung zu der Esthnischen Sprach. Revall: Druckts Chr. Reusner der älter.

Steingrüber, Wilhelm Friedrich 1825. Giebt es wirklich eine bestimmte und unbestimmte Declination in der ehstnischen Sprache, und sind wohl alle Vorschläge, die ehstnische Orthographie betreffend, annehmbar? Beiträge 16, lk 1-25.

Strahlmann, Johann \& Johann Heinrich Rosenplänter 1816. Bruchstück aus einer neuen finnischen Grammatik. Beiträge 4, lk 80-95.

Ziegelmann, Katja 2011. Die Verneinung im Estnischen: Zum Abbau des finiten Verneinungsverbs im älteren Schriftestnischen. Dissertation. Göttingen (https://ediss. uni-goettingen.de/handle/11858/00-1735-0000-0006-AEDC-7 - 21. september 2017).

Tanning, Salme 1961. Mulgi murdetekstid. Eesti murded I. Tallinn: Eesti Riiklik Kirjastus.

Tanning, Salme 2004. Pajusalu, Karl (toim). Karksi murrak. Tallinn: Eesti Keele Sihtasutus.

Tauli, Valter 1972. Eesti grammatika. 1. Hääliku-, vormi- ja sõnã̃petus. Uppsala: Almqvist \& Wiksell.

Tauli, Valter 1973. Standard Estonian Grammar. Part I: Phonology, morphology, wordformation. Uppsala: Almqvist \& Wiksell.

Toomse, Mihkel 1941. Eesti ta-, tä-verbide konsonantsest liitumisest. Tartu: Teaduslik Kirjandus.

Torn-Leesik, Reeli 2016. An investigation of voice constructions in Estonian. Dissertationes Linguisticae Universitatis Tartuensis 26. Tartu: Tartu University Press (http://dspace. ut.ee/handle/10062/49898 - 21. september 2017).

Tragel, Ilona \& Habicht, Külli 2017. Saama-verb grammatilistes konstruktsioonides. Keel ja Kirjandus 1, lk 22-40 (http://kjk.eki.ee/ee/issues/2017/1/879 - 21. september 2017).

Uibo, Heli 1999. Eesti keele sõnavormide arvutianalüüs ja -süntees kahetasemelist morfoloogiamudelit rakendades. Magistritöö. Käsikiri Tartu Ülikooli eesti ja üldkeeleteaduse instituudis (http://www.cs.ut.ee/ heli_u/magistritoo.html-21. september 2017).

Uibo, Udo \& Erelt, Mati 1982. Eesti keele ühemehegrammatika. Keel ja Kirjandus 4, lk 213-218. 
Univere, Aili 1996. Idamurde tekstid. Eesti murded IV. Tallinn: Eesti Keele Instituut. Valmet, Aino 1956. Pluurali partitiiv eesti vanemas kirjakeeles (1524-1857). Kandidaadiväitekiri. Käsikiri Tartu Ülikooli eesti ja üldkeeleteaduse instituudis (http:// dspace.ut.ee/handle/10062/28998 - 27. juuni 2017).

Veske, Mihkel 1879. Eesti keele healte õpetus ja kirjutuse wiis. Tartus: Schnakenburgi trükk ja kulu.

Vihman, Virve-Anneli 2002. Impersonalized Impersonals. Argument structure and language change. Proceedings of the 2002 TAAL Postgraduate Conference, University of Edinburgh (http://www.lel.ed.ac.uk/ pgc/archive/2002/proc02/vihman02.pdf - 21. september 2017).

Vihman, Virve-Anneli 2007. Impersonaliseeritud impersonaal kui konstruktsioonitasandi grammatisatsioon. Emakeele Seltsi aastaraamat 52 (2006), lk 158-178 (http://www. emakeeleselts.ee/esa/ESA_52_pdf/Vihman.pdf - 21. september 2017).

Viitso, Tiit-Rein 1976. Eesti muutkondade süsteemist. Keel ja Kirjandus 3, lk 148-162.

Viitso, Tiit-Rein 2003. Rise and development of the Estonian language. Erelt, Mati (toim). Estonian language. Linguistica Uralica: Supplementary series 1. Tallinn: Estonian Academy Publishers, lk 130-230.

Viitso, Tiit-Rein 2005. Eesti tegusõna tüpoloogiat. Keel ja Kirjandus 3, lk 182-194.

Viks, Ülle 1977. Klassifikatoorse morfoloogia põhimõtted. Preprint KKI-9. Eesti NSV Teaduste Akadeemia Ühiskonnateaduste Osakond. Tallinn.

Viks, Ülle 1978. Morfoloogilise klassifikatsiooni optimeerimisest. Viks, Ülle \& Pall, Valdek (toim). Sõnast tekstini. Tallinn: Eesti NSV Teaduste Akadeemia, lk 91-111.

Viks, Ülle 1980. Klassifikatoorne morfoloogia. Verb. Tallinn: Valgus.

Viks, Ülle 1982a. Klassifikatoorne morfoloogia. Noomen. Tallinn: Valgus.

Viks, Ülle 1982b. Ühest morfoloogilisest klassifikatsioonist. Keel ja Kirjandus 10, lk 517-525; 11, lk 575-586.

Viks, Ülle 1992. Väike vormisõnastik. Tallinn: Eesti Teaduste Akadeemia Keele ja Kirjanduse Instituut.

Wiedemann, Ferdinand Johann 1875. Grammatik der Ehstnischen Sprache. St-Pétersbourg: Imprimerie de l'Académie Impériale des sciences. 


\title{
Summary
}

\section{A short history of research on Estonian inflection}

\author{
Annika Viht \\ Lecturer of Estonian \\ Tallinn University, School of Humanities \\ annika.viht@tlu.ee
}

Keywords: grammar, history of linguistics, inflection, linguistic theory, research fields

During the 17th and 18th centuries, Estonian inflection was described in the traditional framework of Latin grammar. Grammars still differed from one another. For example, Johann Gutslaff observed that the case forms which were traditionally included in the Latinized case paradigm and other Estonian word forms were actually formed the same way. Johann Hornung's grammar started a new era by offering a more vernacular-based description of Estonian inflection than in previous grammars.

An active search for alternative ways to describe Estonian inflection took place in the first half of the 19th century. Both verbal and nominal paradigms received novel interpretations, and mutation was for the first time treated systematically. The nature of case and the contents of the case paradigm were the most popular topics. The first complete overview of the Estonian inflectional system which followed the new ideas was compiled by Eduard Ahrens.

In the second half of the 19th century, the thorough descriptive grammar by Ferdinand Johann Wiedemann and the first grammars in the Estonian language were published.

The first disciplines of emerging Estonian linguistics, historical linguistics and dialectology evolved during the 1920s-1930s under the leadership of Andrus Saareste, Julius Mägiste and others.

The 1940s-1950s were shadowed by war and the beginning of the Soviet occupation. Linguistic research was neither particularly productive nor novel, and the fields and methods remained largely the same as before. Arnold Kask began his thorough studies on the history of literary Estonian, which in time developed into a fruitful research discipline under his influence.

The 1960s-1990s was a period characterized by intensive attention to inflection theory. First, Estonian word forms were described using the internationally well-known IA and IP models. Then, Ülle Viks, Toomas Help, Henn Saari and Martin Ehala all developed their own morphological models. Research was influenced by novel methods and insights, e.g. the theory of natural morphology and the center-periphery view of linguistic phenomena. Huno Rätsep suggested a new interpretation of Estonian moods, giving evidentiality a distinctive role. Toomas Help and Joel Nevis examined some case morphemes as clitics instead of the traditional interpretation as case affixes. A thorough descriptive grammar was compiled (1993-1995). Its inflection chapter, authored by Kristiina Ross, differed radically from the previous grammars and relied on the morphological classification of Ülle Viks and the model of regular and irregular morphology by Toomas Help. Some new disciplines emerged: first-language acquisition, the study 
of colloquial language and computational linguistics. The research of Mati Hint, in particular, revealed major systematic differences between formal and colloquial inflection. Traditional disciplines flourished as well. Among other works, many important general treatments were published: a history of the noun paradigm by Huno Rätsep, a history of literary Estonian by Arnold Kask, a systematic overview of contemporary inflection by Jaak Peebo and comprehensive overviews of several Estonian dialects.

The most important theoretical works of the new millennium include the descriptions of Estonian verb and noun inflection using the WP model by James Blevins. Studies on colloquial Estonian have revealed some ongoing changes in morphological paradigms. Second-language acquisition and the study of language disorders have developed into full-fledged research areas. Of the existent disciplines, first-language acquisition, dialectology, the history of literary Estonian and research on colloquial Estonian have been productive. Diachronic inflection, on the other hand, has received less attention than before. Recently, research on morphosyntax has prevailed over the study of inflection. 